\title{
The Emerging Role of Inflammasomes as Central Mediators in Inflammatory Bladder Pathology
}

\author{
Brian M. Inouye Francis M. Hughes, Jr. Stephanie J. Sexton \\ Department of Surgery, Division of Urology, Duke University Medical Center, Durham, NC, USA
}

J. Todd Purves

\section{Key Words}

Inflammasomes $\cdot$ NLRP3 • Bladder outlet obstruction • Urinary tract infection - Urothelial carcinoma . Bladder cancer

\section{Abstract}

Irritative voiding symptoms (e.g. increased frequency and urgency) occur in many common pathologic conditions such as urinary tract infections and bladder outlet obstruction, and these conditions are well-established to have underlying inflammation that directly triggers these symptoms. However, it remains unclear as to how such diverse stimuli individually generate a common inflammatory process. Jürg Tschopp provided substantial insight into this conundrum when, working with extracts from THP-1 cells, he reported the existence of the inflammasome. He described it as a structure that senses multiple diverse signals from intracellular/extracellular sources and pathogens and triggers inflammation by the maturation and release of the pro-inflammatory cytokines interleukin-1 $\beta$ and interleukin- 18 . Recently, many of these sensors were found in the bladder and the nucleotide-binding domain, leucine-rich-containing family, pyrin domain-containing-3, has been shown to be a central mediator of inflammation in several urological diseases. In this review, we introduce the nucleotide-binding domain, leucine-rich-containing family, pyrin domaincontaining-3 inflammasome, highlight its emerging role in several common urologic conditions, and speculate on the potential involvement of other inflammasomes in bladder pathology.

Copyright $\odot 2017$ S. Karger AG, Basel

\section{Introduction}

The bladder lumen is a hostile environment. Under normal conditions chemicals or microbes in the urine are denied entry into the bladder wall by a glycosaminoglycan layer at the luminal surface of the urothelium. If this layer is compromised by invasive uropathogens, mechanical trauma (stones, catheters, etc.) or idiopathically in the case of interstitial cystitis, a host of potentially dangerous components gain access to the underlying tissue. Even with an intact barrier, the urothelium may be significantly altered in certain pathological conditions by physical changes such as elevated intravesical pressure, overstretch of tissues, hypoxia/reperfusion or products of metabolic dysregulation. The near ubiquitous response to this plethora of insults is the appearance of an inflammatory state. Despite the pervasive inflammation, there has been no clear understanding of the mechanism by which such diverse factors could trigger this common response. Inflammation in response to a wide range of agents is not unique to the bladder and in 2002 Jürg Tschopp began to shed light on this quandary in immune cells when his group discovered the existence of the inflammasome; a multimeric structure that senses diverse stress signals and triggers inflammation by the maturation and release of the pro-inflammatory cytokines interleukin-1 $\beta$ (IL$1 \beta$ ) and IL-18 [1]. Recently, the inflammasome has also emerged as a central mediator linking bladder insults to bladder inflammation and, ultimately, to bladder pathology $[2,3]$.

\section{KARGER}

두 2017 S. Karger AG, Basel

Fax +4161306 1234

E-Mail karger@karger.com

www.karger.com
Accessible online at: www.karger.com/cur
Francis M. Hughes, Jr.

Department of Surgery, Division of Urology

Duke University Medical Center

P.O. Box 3831

Durham, NC 27710 (USA)

E-Mail monty.hughes@duke.edu 


\section{Introduction to the Inflammasome}

After the mechanical catharsis of micturition and the barrier provided by the glycosaminoglycan layer, the bladder's next line of defense is the innate immune system and the triggering of inflammation [4]. Cells that comprise the innate system rely on a set of receptors, collectively known as pattern recognition receptors, to detect relevant signals and initiate a response. These receptors are expressed by many different cell types including fibroblasts, myeloid immune cells, and epithelial cells [5]. The pattern recognition receptors are classified into 5 families: toll-like receptors (TLRs), C-type lectin receptors, retinoic acid-inducible gene-I (RIG-1)-like receptors, absent in melanoma 2 (AIM2)-like receptors, and nucleotide-binding oligomerization domain (NOD)like receptors (NLRs) [6].

NLRs are located intracellularly where they recognize 2 different types of signals, pathogen-associated molecular patterns (PAMPs) and danger (or damage) associated molecular patterns (DAMPs) [6]. PAMPs include common bacterial components and known virulence factors, such as lipopolysaccharide (LPS), flagellin, and hemolysins [5]. DAMPs are typically released by stressed, damaged or dying cells and include adenosine triphosphate (ATP), uric acid crystals, high-mobility group box 1, and heat-shock proteins [6]. A list of DAMPs and PAMPs particularly relevant to the urologic system is shown in table 1 .

The NLR protein family is large and diverse with over 20 known members in humans, many of which may contribute to the innate immune response in different ways. For example, some NLRs (NOD1, NOD2) stimulate transcription of NF- $\kappa \mathrm{B}$-regulated genes [7] whereas others assist the adaptive immune response by triggering transcription of major histocompatibility class II genes for antigen-presenting cells [8]. However, NLRs are best known for those that assemble into cytosolic multi-protein complexes called inflammasomes, which are typically named for the NLR involved. For example the inflammasome formed with nucleotide-binding domain, leucine-rich-containing family, pyrin domaincontaining-3 (NLRP3) is known simply as the NLRP3 inflammasome. Formation of the inflammasome triggers the cleavage of pro-caspase- 1 into active caspase-1. Caspase- 1 cleaves pro-IL- $1 \beta$ and pro-IL-18 into their active forms (IL-1 $\beta$ and IL-18) along with gasdermin D, which triggers pyroptosis $[9,10]$, a pro-inflammatory form of cell lysis. Pyroptosis in turn releases the mature IL-1 $\beta$ and IL-18 as well as intracellular DAMPs such as ATP,
Table 1. A list of the known DAMPs and PAMPs that trigger inflammasome activation in bladder pathology

\begin{tabular}{ll}
\hline DAMPs & PAMPs \\
\hline ATP & lipopolysaccharide \\
Uric acid (monosodium urate) & flagellin \\
High-mobility group box 1 & viral double-stranded RNA \\
Albumin & viral single-stranded RNA \\
Mitochondrial DNA & lipoteichoic acid \\
Cytosolic RNA & $\alpha$-hemolysin \\
Heat-shock proteins & $\beta$-hemolysin \\
Mitochondrial cardiolipin & \\
Lysosomal cathepsin & \\
Acrolein & \\
Calcium oxalate & \\
\hline
\end{tabular}

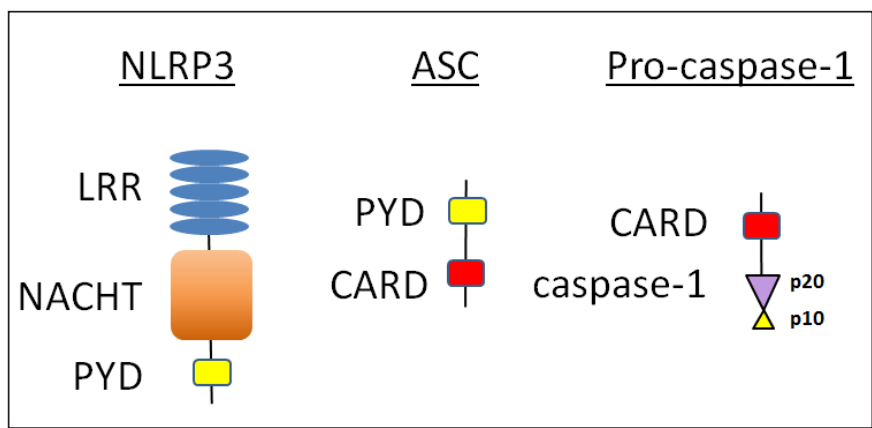

Fig. 1. Domain structure of the components of the NLRP3 inflammasome. The NLRP3 inflammasome contains 3 components: 1) NLRP3 (the nod-like receptor), 2) ASC, and 3) procaspase-1. NLRP3 consists of 3 separate domains: a C-terminal LRR domain, a NACHT domain and an N-terminal PYD. ASC is composed of a PYD and a CARD, and is the adaptor protein that binds pro-caspase-1. Pro-caspase- 1 has a CARD and 2 subunits (p20 and p10) which are cleaved to form active caspase- 1 by the inflammasome.

uric acid, and high-mobility group box 1 that further propagate inflammation [11, 12]. Additionally, some other PPRs can form inflammasomes such as RIG-1 and AIM2 [13, 14].

\section{The NLRP3 Inflammasome}

The best-studied member of the NLR family is NLRP3, which plays important roles in a wide variety of inflammatory pathologies. Unlike many other NLRs, NLRP3 is activated by both PAMPs and DAMPs [15-17] making it ideally suited to play a central role in the innate 


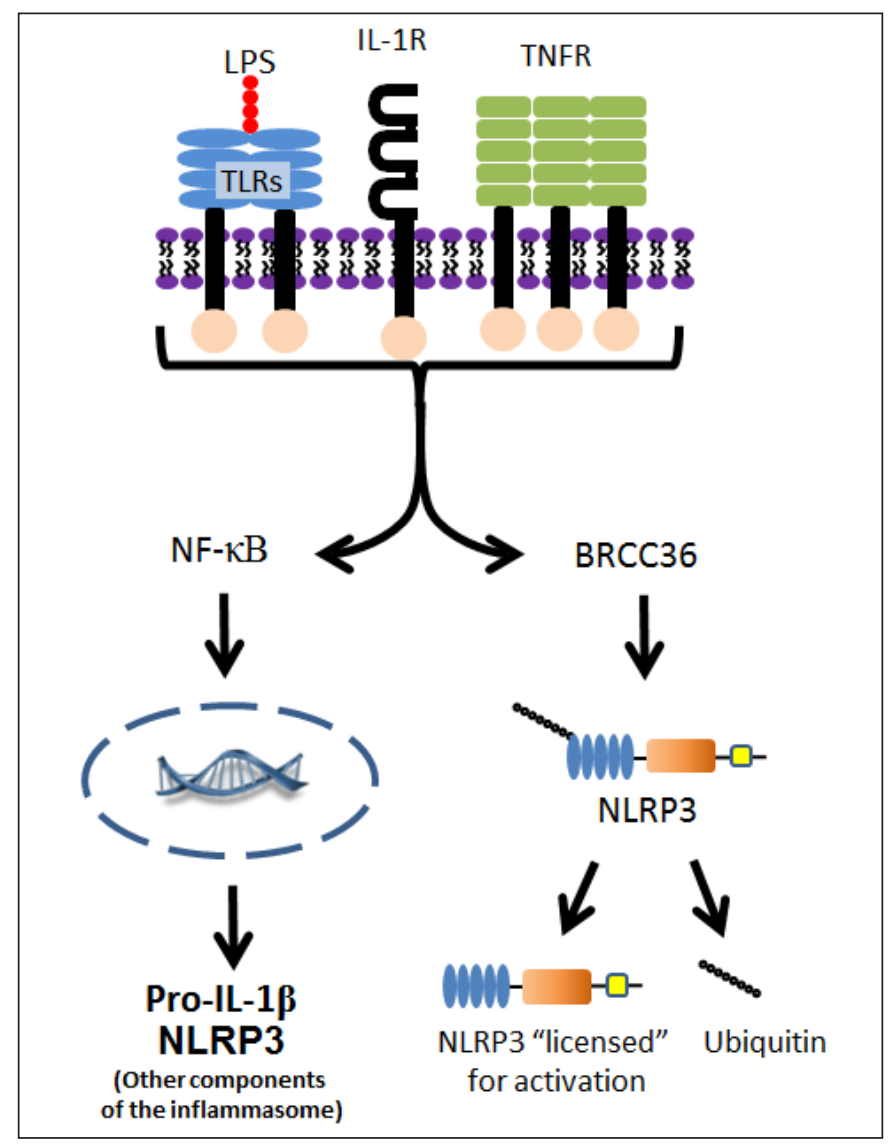

Fig. 2. Priming of the NLRP3 inflammasome in the canonical pathway. The canonical pathway of NLRP3 inflammasome activation requires a priming step. This occurs when a DAMP or PAMP (such as LPS) binds to a non-NLR receptor (such as TLR) or there is signaling though IL-1R or tumor necrosis factor receptor. The effect of this binding leads to further signaling through

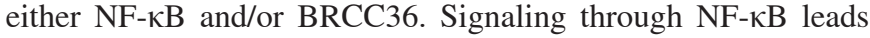
to production of de novo pro-IL-1 $\beta$ and other components of the NLRP3 inflammasome while signaling through BRCC36 leads to deubiquination of existing NLRP3. Deubiquination then frees NLRP3 to be activated, i.e. "licenses" it for activation.

immune response. In an early tissue survey of NLRP3 expression, Kummer et al. [18] documented the presence of NLRP3 in the human bladder, and our lab has subsequently confirmed its expression in the rat and localized it to the urothelial layer [19].

The domain structure of the components of the NLRP3 inflammasome is shown in figure 1 and is important to assembly. NLRP3 contains 3 separate domains; an N-terminal pyrin (PYD) domain that mediates homotypic binding, a nucleotide-binding and oligomerization (NACHT) domain that mediates ATP-dependent

Inflammasomes in Bladder Pathology oligomerization, and a C-terminal leucine-rich repeat (LRR) domain that senses ligand (in the case of NLRP3 probably indirectly). While other NLRs also have caspase recruitment domains (CARDs) as part of their primary sequence, NLRP3 requires an adaptor protein to connect to pro-caspase-1. The adapter is known as apoptosis-associated speck-like protein containing a CARD (ASC) and consists of a PYD and a CARD. Pro-caspase- 1 has a CARD and 2 subunits (p20 and p10) that become part of the final enzyme.

Activation of the NLRP3 inflammasome can occur by 3 different pathways termed the 1) canonical 2) noncanonical or 3) alternative pathways [11, 20-25]. The canonical pathway requires 2 steps: priming and activation. Priming (fig. 2) begins when a DAMP or PAMP binds to a non-NLR receptor (typically a TLR) or there is signaling through endogenous cytokine receptors such as IL-1R and tumor necrosis factor receptor [26]. Signaling through NF- $\mathrm{KB}$ initiates production of de novo proIL-1 $\beta$ and NLRP3 $[15,26,27]$ while signaling through BRCC36 deubiquitinates preexisting NLRP3 [28, 29], licensing it to form an inflammasome.

Canonical activation of NLRP3 (fig. 3) can be triggered in different models by different DAMPs and PAMPs. Given the large number of agents activating a single target, it seems unlikely to occur by direct ligand binding to NLRP3 and so there has been an intense study to find a common cellular event activating this inflammasome. Reactive oxygen species (ROS) were first proposed to be such an activator [30], but subsequent studies suggests they may dispensable [31]. Thus, the generation of ROS might best be thought of as a pathway to activation induced by certain DAMPs/PAMPs [32]. Likewise, $\mathrm{Ca}^{2+}$ signaling was suggested as a general requirement by several studies [33-35] but that too has been challenged [36]. Currently the prevailing theory is that $\mathrm{K}^{+}$efflux represents a common denominator in the canonical pathway of NLRP3 activation [31, 37, 38]. However, how that may translate to NLRP3 assembly is unknown and $\mathrm{K}^{+}$ loss is not excusive to inflammasome activation but is a well-established event in apoptosis as well [39-41].

Regardless of the trigger, once assembly is initiated, the catalytic domain of the never in mitosis gene A-related kinase 7 [42, 43] interacts with the LRR domain of NLRP3 causing the NLRP3 to oligomerize through binding of NACHT domains. The NLRP3 oligomer then binds ASC, through homotypic binding of pyrin domains, which forms long filaments that bind multiple molecules of pro-caspase-1 (fig. 3 depicts only a dimer for simplicity). This large (up to $1 \mu \mathrm{m}$ ) structure is surprisingly sta- 


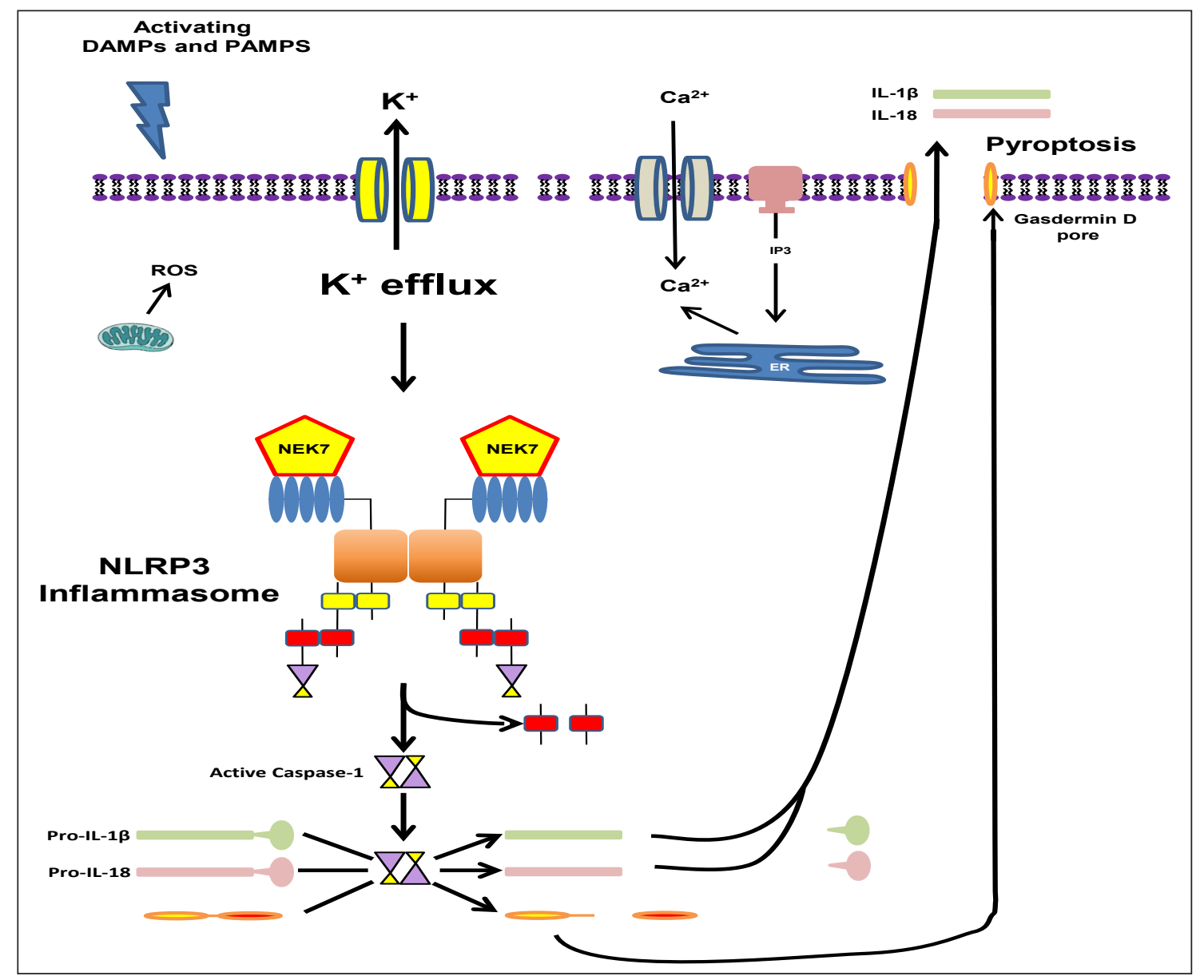

Fig. 3. Activation of the NLRP3 inflammasome in the canonical pathway. The second step of the canonical pathway is activation. DAMPs and PAMPs trigger this step and lead to activation of the NLRP3 inflammasome. Proposed cellular events involved include ROS, $\mathrm{Ca}^{2+}$ signaling, and, most likely, $\mathrm{K}^{+}$efflux. Regardless, NLRP3 inflammasome assembly is initiated and the catalytic domain of the never in mitosis gene a-related kinase 7 interacts with the LRR domain of NLRP3 causing oligomerization through binding of NACHT domains (the figure depicts only a dimer for simplicity). This leads to NLRP3 binding to ASC and ASC in turn binding to procaspase-1. Pro-caspase-1 molecules in close proximity lead autocatalytic cleavage of pro-caspase- 1 to caspase- 1 (induced proximity). Activated caspase- 1 then cleaves pro-IL-1 $\beta$ and pro-IL-18 into their active forms (IL- $1 \beta$ and IL-18). Caspase-1 also cleaves gasdermin $\mathrm{D}$ whose $\mathrm{N}$-terminus is responsible for forming a pore that results in pyroptosis and the release of IL-1 $\beta$ and IL-18.

ble and is often known as an ASC-speck. Typically only one of these form per cell and it incorporates all the ASC in that cell. Holding pro-caspase-1 molecules in close proximity in this speck results in an autocatalytic cleavage process known as induced proximity. This cleaves caspase- 1 into its $\mathrm{p} 20$ and p10 subunits which associate with an additional set of $\mathrm{p} 20$ and p10 subunits to form an active tetramer. Both the active caspase- 1 and the CARD domain dissociate from the speck and caspase-1 then cleaves pro-IL-1 $\beta$ and pro-IL-18 into their active forms
(IL-1 $\beta$ and IL-18). Caspase-1 also cleaves gasdermin D [10] whose $\mathrm{N}$-terminus is responsible for forming a pore in the cell membrane that results in pyroptosis [44-46].

The NLRP3 inflammasome can also be activated by a non-canonical pathway (fig. 4) where LPS in the cytosol directly binds to the CARD domain of caspase-11 (in rodents; caspase-4 and caspase-5 in humans) $[9,47$, 48]. This triggers the oligomerization and activation of caspase-11, which can directly cleave gasdermin D and cause pyroptosis, without promoting inflammasome for- 


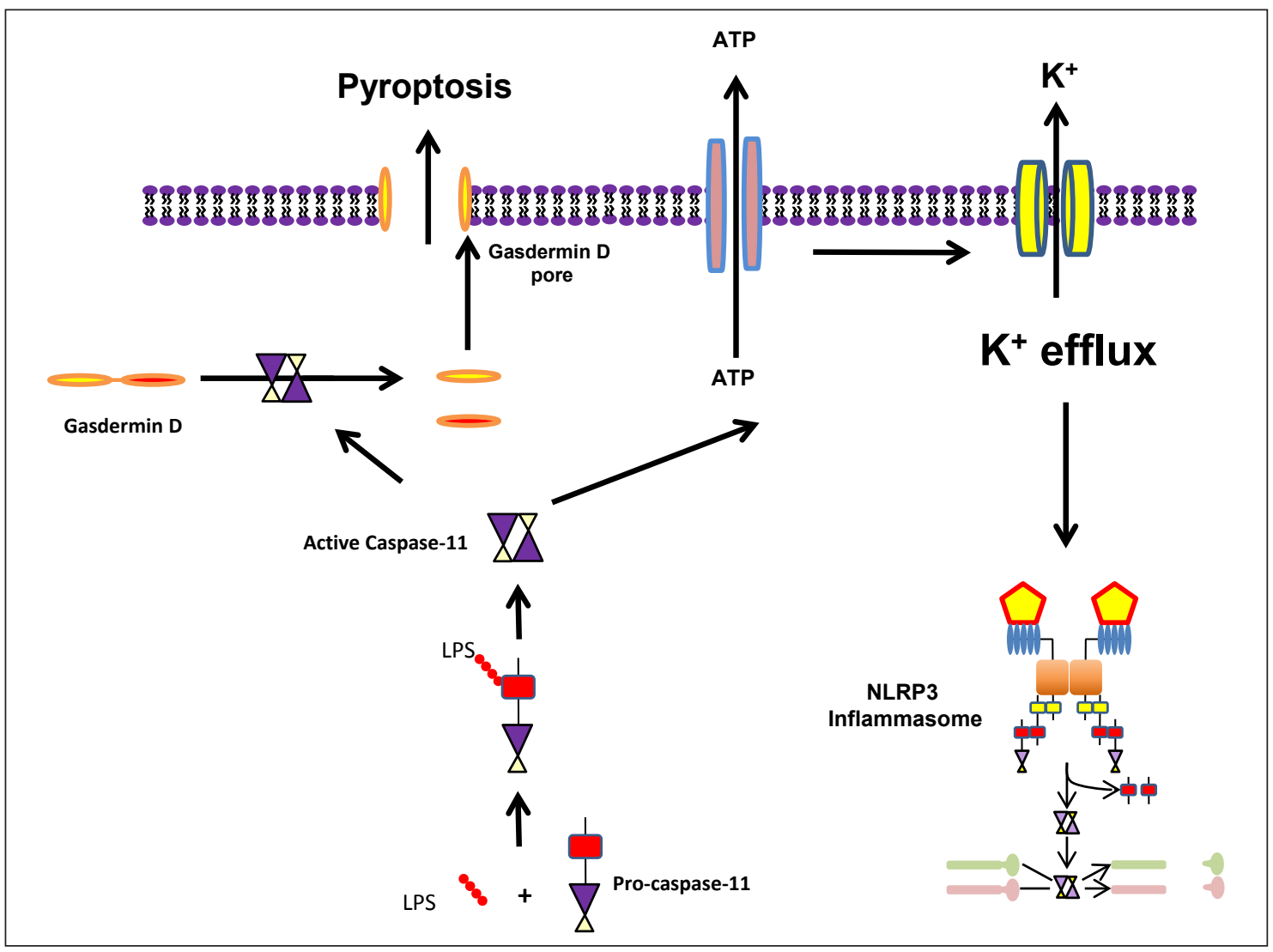

Fig. 4. Non-canonical pathway of NLRP3 inflammasome activation. NLRP3 activation in the noncanonical pathway requires activation of caspase-11 through direct binding to a cytosolic PAMP, like LPS, which then facilitates the oligomerization of the caspase. Caspase- 11 can directly cleave gasdermin D and cause pyroptosis or can lead to the release of ATP that acts as a DAMP, stimulating $\mathrm{K}^{+}$loss and the assembly of the NRP3 inflammasome with subsequent maturation of IL- $1 \beta$ and IL-18.

mation or cytokine production. Caspase-11 can also lead to the release of ATP, which can stimulate $\mathrm{K}^{+}$loss and the assembly of the NRP3 inflammasome, leading to the release of IL-1 $\beta$ and Il-18. Like the canonical pathway, $\mathrm{K}^{+}$ efflux is also characteristic of the noncanonical pathway. The importance and uniqueness of the non-canonical pathway have been highlighted by decreased mortality in caspase-11-deficient mice exposed to systemic administration of LPS [47, 49].

There is a third mechanism of NLRP3 activation (fig. 5), known currently as the alternative pathway that has been shown in human monocytes, although the extent of its deployment across cell types has not been thoroughly examined [23-25, 50]. Similar to the canonical pathway, the alternative pathway relies on LPS binding to TLR4 to upregulate NLRP3 and pro-IL-1 $\beta$ production. However, unlike the canonical pathway, the efflux of $\mathrm{K}^{+}$is not required [50]. Instead, TLR4 signaling leads to toll/ interleukin-1 receptor-domain-containing adapter-inducing interferon- $\beta$, receptor-interacting protein kinase 1 , Fas-associated protein with death domain, and caspase- 8 acting downstream to activate the NLRP3 inflammasome leading to cleavage of pro-IL- $1 \beta$ to IL-1 $\beta$. Even though the inflammasome requires ASC and caspase- 1 for this cleavage, there is no evidence for ASC speck formation or pyroptosis in this pathway [23, 25].

\section{Urologic Pathology Dependent on Inflammasomes}

The NLRP3 inflammasome was first discovered to mediate bladder inflammation in a cyclophosphamide-induced hemorrhagic cystitis model [51]. Since that time, inflammasomes have been implicated in both sterile and 


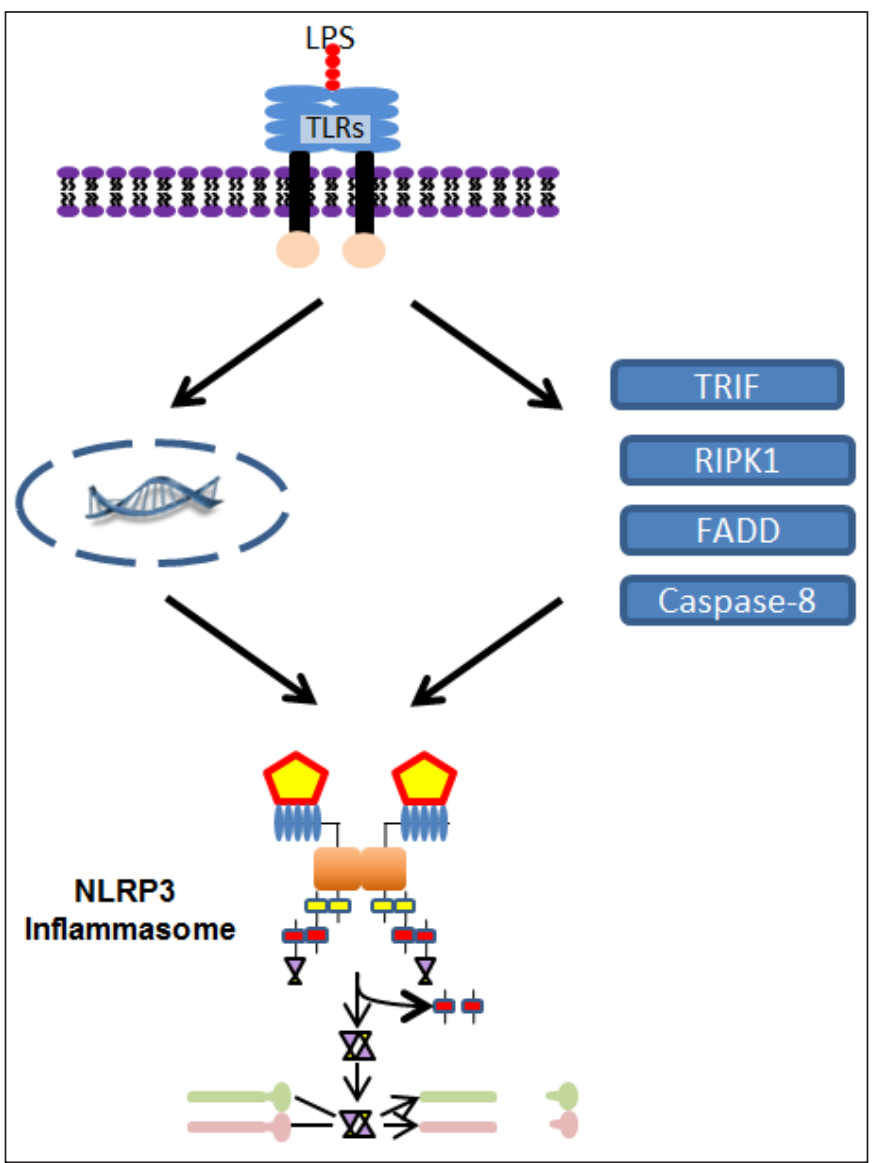

Fig. 5. Alternative pathway of NLRP3 inflammasome activation. The alternative pathway is the third mechanism of NLRP3 inflammasome activation. Similar to the canonical pathway's priming step, LPS binds to TLR4 that leads to upregulation of NLRP3 and pro-IL-1 $\beta$ through the NF- $\kappa \mathrm{B}$ pathway. However, instead of the $\mathrm{K}^{+}$efflux, NLRP3 inflammasome activation relies on toll/interleukin-1 receptor-domain-containing adapter-inducing interferon- $\beta$, receptor-interacting protein kinase 1 , Fas-associated protein with death domain, and caspase- 8 that are upregulated by the TLR 4 signaling.

infectious cystitis, as well as malignancy. The following sections will discuss the role of inflammasomes in cyclophosphamide-induced hemorrhagic cystitis, bladder outlet obstruction (BOO), urinary tract infections (UTI), and bladder cancer.

\section{Cyclophosphamide-Induced Hemorrhagic Cystitis}

Cyclophosphamide is a widely used chemotherapeutic agent and acrolein, the metabolic byproduct of cyclophosphamide, is stored in the bladder prior to excretion where it damages the urothelium and can cause hemorrhagic cystitis. Fortunately, its occurrence in the patient population has been minimized primarily through the use of super hydration and 2-mercaptoethane sulfonate sodium, which chelates the acrolein in the urine and masks its toxic effects. However, it remains a useful experimental model to study the mechanisms of sterile bladder inflammation. Suggestive of a role for the inflammasome in this model, Smaldone et al. [52] reported an increase in urinary IL-1 $\beta$ and IL-18. Moreover, Ribeiro's group [5355] used the IL-1 receptor antagonist anakinra in mice to directly demonstrate a causative role for IL- $1 \beta$. Recently, our group inhibited NLRP3 in rats using glyburide, an FDA-approved diabetic medication and known inhibitor of the NLRP3 inflammasome [56]. Addition of this inhibitor diminished the changes associated with irritative voiding (increased frequency, decreased volume) along with reducing IL-1 $\beta$ and IL-18 levels and suppressing inflammation [51]. Haldar et al. [57] further refined the underlying mechanism by demonstrating that acrolein oxidizes mitochondrial DNA while epigenetically silencing DNA repair enzymes. The oxidized DNA then triggers NLRP3 inflammasome activation. Furthermore, IL-1 $\beta$, acting downstream through insulin-like growth factor, induces bladder smooth muscle hyperplasia, a well-known change in this model that could be a contributor to the irritative voiding changes [57]. Taken together the findings of several investigators demonstrate that the NLRP3 inflammasome is critical in mediating biochemical, histological, and physiological inflammation during cyclophosphamide-induced hemorrhagic cystitis.

\section{$B O O$}

$\mathrm{BOO}$ is most often the result of benign prostatic hyperplasia (BPH) in older men, but may also occur after urethral stricture disease, pelvic organ prolapse, neurological trauma/disease, or in children with posterior urethral valves. BOO causes physical changes in the bladder, which leads to chronic inflammation [58-63] that evokes clinically bothersome, irritative voiding symptoms that are difficult to treat using available therapies. Our lab has explored the role of the NLRP3 inflammasome in a rat model of $\mathrm{BOO}$ in which the animals are treated with NLRP3 inhibitor glyburide before and during development of this disorder. We found that NLRP3 is activated in the acute period of $\mathrm{BOO}$ and is responsible for triggering the resulting inflammation and bladder hypertrophy [62]. Urodynamic studies of BOO rats demonstrated that glyburide prevented the increase in urinary frequency and decrease in void volume characteristic of irritative voiding symptoms seen during $\mathrm{BOO}$ in patients. Treatment with glyburide also led to a longer duration of void- 


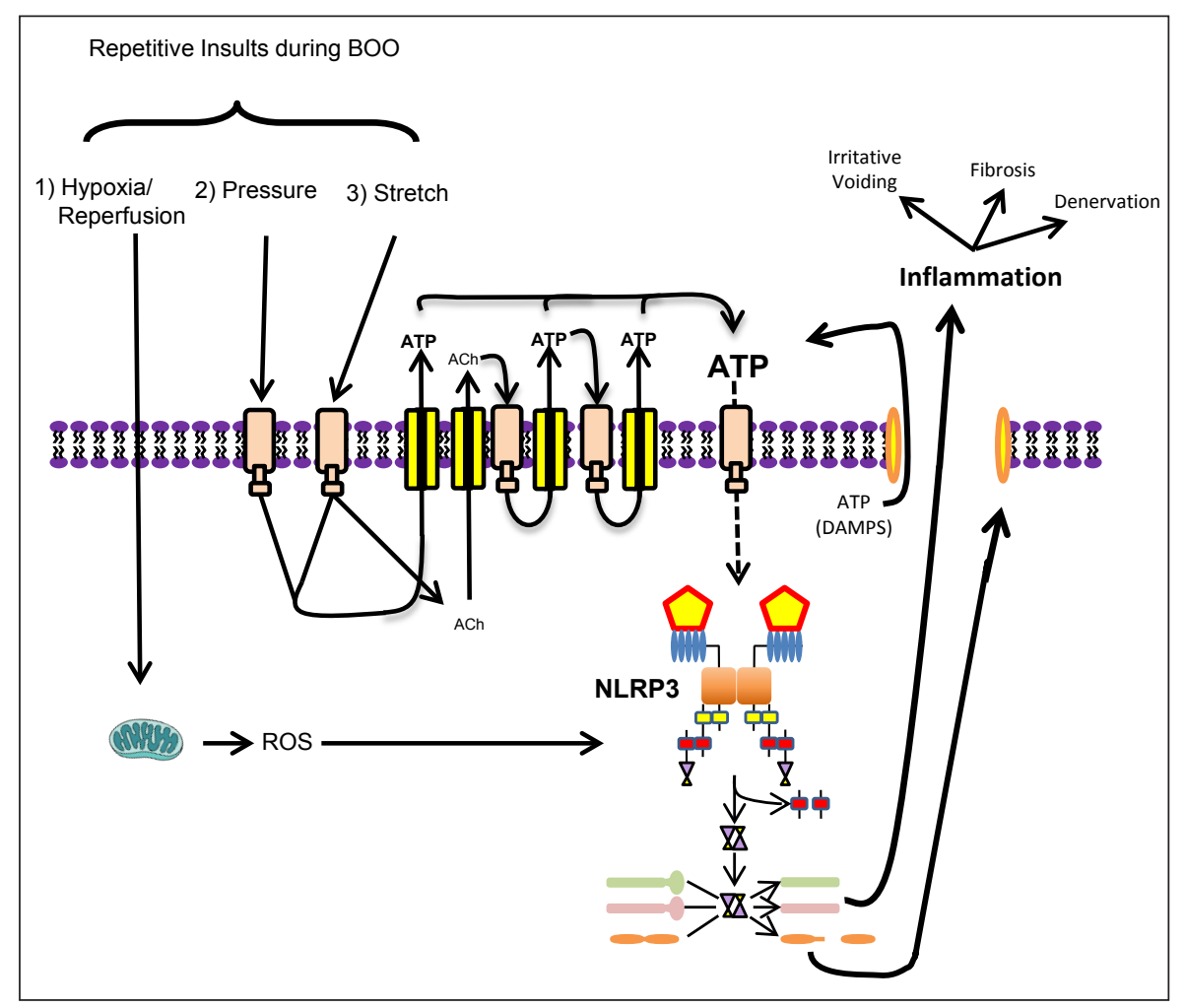

Fig. 6. NLRP3 inflammasome activation in BOO. The NLRP3 inflammasomes is thought to be activated by at least 3 repetitive insults during BOO: hypoxia/reperfusion, high pressure and increased stretching. Hypoxia/reperfusion leads to production of ROS, a known trigger for the inflammasome. Increased pressure and repetitive stretch both release ATP, a known NLRP3 DAMP. Furthermore, bladder stretching releases acetylcholine that can act back on cholinergic receptors to trigger release of more ATP. The increase in extracellular ATP caused by pressure, stretch, and acetylcholine can drive yet another positive feedback loop known as ATP-dependent ATP release. The result is a tremendous amount of extracellular ATP, which then serves as a trigger for NLRP3 activation.

ing, leading us to conclude that blocking inflammation allowed the detrusor muscle to maintain a longer, stronger contraction, not surprising given that non-inflamed muscles can sustain a contraction longer then inflamed ones. Strong genetic evidence for the importance of the NLRP3/IL-1 $\beta$ pathway in BOO pathology was also provided by Kanno et al. [64] who found that inflammatory endpoints in obstructed mice were diminished in IL-1 $\beta^{-/-}$ strains.

Inflammasomes, and NLRP3 in particular, can have very specific activating stimuli, although the exact mechanism of NLRP3 activation in response to BOO has not been defined. We propose that at least 3 potential inflammasome-activating insults occur repeatedly following obstruction. As shown in figure 6, those insults are hypoxia/reperfusion, increased pressure, and repetitive stretching. Both hypoxia and reperfusion are known to trigger the release of ROS and ROS is a well-known trigger for NLRP3 [11, 21, 65], if not a universal event. Due to incomplete emptying, inflammation, hypertrophy, and more, obstructed bladders are greatly enlarged compared to controls and undergo excessive distension during filling. This stretch reduces the diameter of blood vessels within the bladder wall, reducing blood flow and creating a mildly hypoxic environment [66]. Micturition relieves this partial occlusion resulting in reperfusion which brings a bolus of oxygen into the tissue that drives a burst of oxidative phosphorylation in the mitochondria and a surge of ROS, a well-known trigger for NLRP3 $[11,21,65]$. 
The potential also exists for NLRP3 to be activated by both increased pressure and stretch, which may exert their effects additively or synergistically through the release of ATP; a potent activator of NLRP3 [16, 67]. Compared to a normal bladder, an obstructed bladder has a much higher pressure during micturition as the detrusor contracts with greater force to overcome the obstruction. Recently, Nagatomi's laboratory has used urothelial cells in culture to demonstrate that exposure to increased hydrostatic pressure directly stimulates ATP release [68] and NLRP3 activation [69]. The use of purinergic receptor antagonists demonstrated that the released ATP is directly responsible for triggering inflammasome activation (Jiro Nagatomi, personal communication, May 20, 2017) suggesting that pressure-induced release of ATP may play an important part in triggering NLRP3mediated inflammation during BOO. Due to decreased bladder compliance secondary to BOO, the bladder also stretches much more during the storage phase, and increased stretch has been well-established in the literature to trigger the release of ATP [70-74]. Currently, no studies have investigated the ability of stretch to activate the NLRP3 inflammasome, although it is likely to be rich fodder for future studies. In addition to these 2 ATP-releasing mechanisms, the literature suggests the presence of an amplifying loop within the urothelia. Increased stretch stimulates the release of acetylcholine in addition to ATP [71, 75-77]. While this acetylcholine may have effects on nearby nerves, it can also act on cholinergic receptors in the urothelia to trigger release of more ATP $[78,79]$. The increase in extracellular ATP caused by pressure, stretch, and acetylcholine can drive yet another positive feedback loop known as ATP-dependent ATP release [80]. The ultimate result is a substantial amount of ATP just outside the cell membrane. All of this ATP from the individual cell would be joined by ATP released from neighboring cells undergoing pyroptosis, magnifying this feed forward loop and propagating inflammation during BOO. While additional studies need to be performed to quantify the impact of such a feed forward loop, the literature clearly indicates that repetitive insults associated with BOO trigger an ongoing inflammatory process mediated by NLRP3 that evokes negative downstream events such as irritative voiding and fibrosis.

The harmful effects of an acute episode of BOO can typically be alleviated by simply removing the obstruction. However, in patients with chronic BOO (such as seen with $\mathrm{BPH}$ ) de-obstruction is not always successful in restoring normal bladder function because the bladder has become decompensated and thus dysfunctional.
The changes underlying decompensation are complex but certainly involve at least 2 major, potentially irreversible, changes to the bladder; fibrosis and denervation. Numerous studies in pulmonary, cardiac, and renal systems have demonstrated a link between the NLRP3 inflammasome and the induction of fibrosis [81-84] and we have recently shown a similar link in the bladder [61]. In those studies inhibition of NLRP3 with glyburide or IL-1 $\beta$ with a receptor antagonist (anakinra) blocked the appearance of fibrotic endpoints [85]. In vitro, urothelial cells exposed to IL- $1 \beta$ responded by producing collagens and cells harvested from BOO rats secreted more collagen than those taken from control animals. These findings suggest the existence of an IL- $1 \beta$-mediated profibrogenic positive feedback loop within the urothelia that is active during BOO [61].

Loss of bladder nerve density during $\mathrm{BOO}$ has been found in many different species including man [86], pig [87], guinea pig [88], sheep [89], rabbit [90], and rat [91] and is speculated to be triggered by ROS [88, 92], which we have noted is a common activator of NLRP3 [11, 21, 65]. In our rat model of BOO, inhibiting NLRP3 (glyburide) or blocking the IL-1 receptor (anakinra) attenuated the loss of neurons while in vitro experiments demonstrated a direct apoptotic effect of IL- $1 \beta$ on pelvic ganglionic neurons, suggesting 1 mechanism of BOO-induced denervation may be NLRP3/IL-1 $\beta$ triggered apoptosis. The combination of our studies on fibrosis and denervation suggest NLRP3 may be an important therapeutic target for preventing bladder deterioration and decompensation during the progression of $\mathrm{BOO}$.

While the most common cause of $\mathrm{BOO}$ is $\mathrm{BPH}$, it is interesting that $\mathrm{BPH}$ itself may be a result of inflammasome activation [93]. Clearly, infectious prostatitis has the potential to activate inflammasomes through PAMPs, but not all cases of prostatitis are infectious nor does infectious prostatitis necessarily cause BPH. Recently, Kashyap et al. [94] demonstrated that injection of formalin into the prostate upregulated NLRP1, caspase-1, and the cytokines IL-1 $\beta$ and IL-18. Thus, inflammasomes may mediate both infectious and sterile prostatitis, leading to $\mathrm{BPH}, \mathrm{BOO}$, and activation of NLRP3 within the bladder, eventually causing all of the deleterious results just discussed. Intriguingly, the main NLR involved in the prostate appears to be NLRP1, not NLRP3. NLRP1 has also been found in the bladder where its role remains unknown [95].

\section{Uropathogenic E. coli UTIS}

UTIs are the second most common forms of infection behind only the common cold and IL- $1 \beta$ is one of 
the first cytokines detected at the onset, suggesting an early role of inflammasomes in infectious cystitis [96]. While UTIs can be caused by various viral, mycobacterial, chlamydial, fungal, and schistosomal agents, by far the most common culprits are gram-negative, uropathogenic Escherichia coli (UPEC) [97]. UPEC produce LPS, flagellin, and $\alpha$-hemolysin, which are wellknown PAMPs that activate NLR inflammasomes in other tissues. Our lab has recently shown that both LPS and flagellin can trigger inflammasome activation when placed in the lumen of the bladder [51]. Moreover, injection of LPS into the bladder wall triggered irritative voiding reminiscent of UTIs and this pathological effect was blocked by glyburide [98], clearly showing that LPS activation of NLRP3 can evoke a cystitis analogous to what is seen during a UTI. Nagamatsu et al. [99] examined $\alpha$-hemolysin expression in UPEC and found that $\alpha$-hemolysin activated NLRP3 and triggered pyroptosis in human urothelia. This leads to exfoliation of urothelial cells, which is presumed to act as a host defense mechanism against UPEC expressing $\alpha$-hemolysin. This approach is not without its downside however, as exposing the underlying transitional cells can allow the UPEC to penetrate further and form quiescent cellular reservoirs that can lead to chronic cystitis [99].

Perhaps unsurprisingly, given the nature of hostpathogen interactions, UPEC strains that avoid activation of NLRP3 show increased virulence or asymptomatic colonization [100]. For example, Waldhuber et al. [101] found that UPEC strain CFT073 avoids activation of the NLRP3 inflammasome by expressing Toll/IL-1 receptor-containing protein $\mathrm{C}(\mathrm{TcpC})$, a multifunctional protein that inhibits NLRP3 activation by binding both NLRP3 and pro-caspase-1, consequently suppressing the processing and activation of pro-caspase- 1 . TcpC also blocks signaling through the TLRs necessary for priming of NLRP3. Inhibition of TcpC expression resulted in greater activation of NLRP3 and elevated urinary IL-1 $\beta$ secretion compared to mice infected with wildtype UPEC strains [102]. Thus, NLRP3 may be a central player in the host-pathogen interaction during UPEC UTIs.

\section{Group B Streptococcal UTIS}

Inflammasomes have also been implicated in the host response to UTIs by gram-positive bacteria such as Streptococcus agalactiae, a Group B streptococcus (GBS) [103]. Their involvement was suspected when the initial stages of GBS UTIs were found to be characterized by secretion of IL-1 $\beta$ [104]. With uropathogenic GBS, $\beta$-hemolysin (a PAMP) activates the NLRP3 inflammasome by causing lysosomal leakage which permits the escape of GBS RNA (another, independent, PAMP) into the cytosol. Transfection of GBS RNA directly into the cytosol of GBS-infected cells increased IL- $1 \beta$ production while, conversely, introduction of RNase into this compartment decreased cytokine secretion [105]. Although bacterial RNA can clearly be important in inflammasome activation, it is not thought that NLRP3 is directly activated by the RNA. It has been hypothesized that the RNA could initiate the recruitment of mitochondrial antiviral signaling protein that mediates membrane damage through ROS production with subsequent release of intracellular $\mathrm{K}^{+}[106,107]$.

As might be expected, NLRP3-mediated inflammation in response to GBS is important for control of the infection. Costa et al. [103] infected mice with GBS and found that those lacking NLRP3 inflammasome components had increased mortality and an elevated GBS burden compared to controls. In another study, mice lacking IL-1 receptors were also found to be more susceptible to GBS infection compared to controls [108]. Finally, as was seen with UPEC [99], activation of NLRP3 results in urothelial exfoliation, exposing deeper layers and resulting in the formation of quiescent reservoirs leading to chronic UTIs. Thus, NLRP3 seems to be in a delicate balance where its activation is necessary for an adequate host response, but may also contribute to chronic colonization or infection. The therapeutic challenge, then, is to modulate the inflammatory response rather than eliminate it so that the advantageous mechanisms are preserved or enhanced while deleterious effects are minimized.

\section{Bladder Cancer}

While NLRP3 gene polymorphisms have been associated with melanoma, myeloma, and colorectal cancer [109-111], not until recently was there an investigation of the role of inflammasomes in bladder cancer [112]. Poli et al. [112] examined mRNA in urine from human subjects with and without bladder cancer for expression of inflammasome components and cytokeratin 20 mRNA (CK20), a marker of urothelial differentiation that is highly expressed in bladder cancer [113]. They found that compared to healthy controls, patients with bladder cancer on biopsy had an increased expression of NLRP3 and NLR family apoptosis inhibiting protein [NAIP; an important adaptor for the NLR containing a caspase recruitment domain 4 (NLRC4) inflammasome]. In addition, NLRP3 expression was increased in lowgrade tumors, while NAIP expression was increased in 


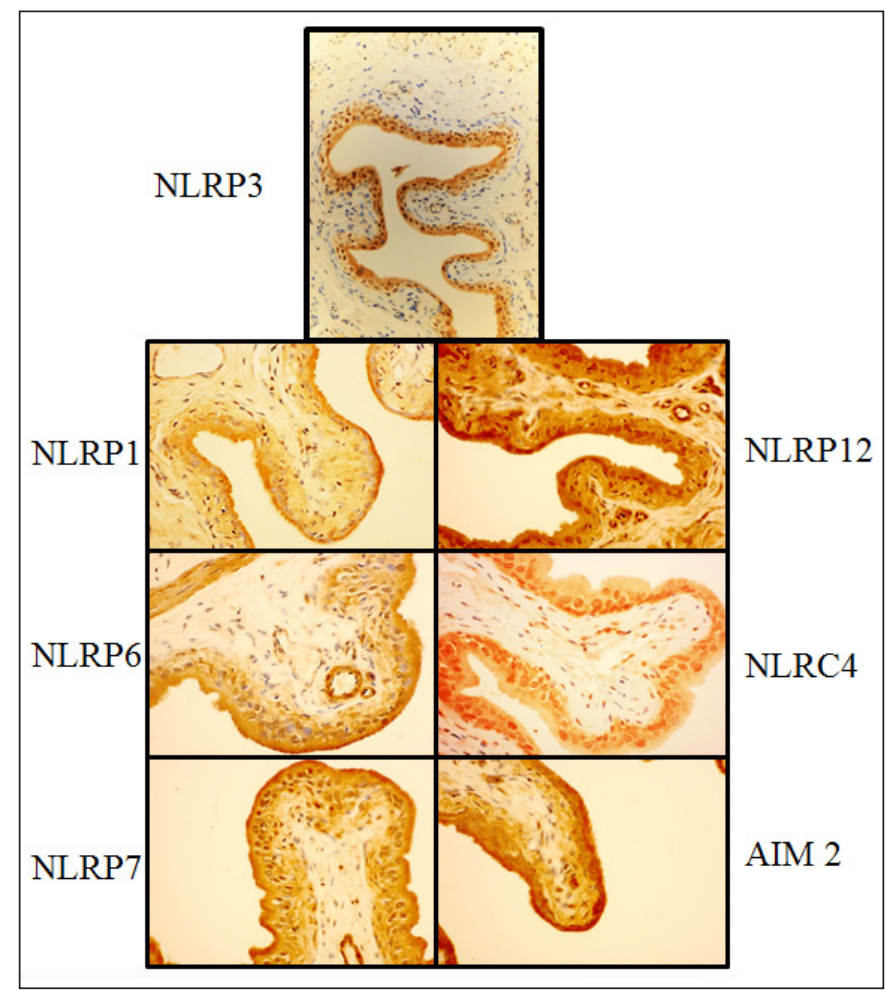

Fig. 7. Immunohistochemistry localizing inflammasomes to the urothelium. Antibody staining of rat bladders for NLRP1, NLRP3, NLRP6, NLRP7, NLRP12, NLRC4, and AIM2 and photographed at high magnification. Differential staining demonstrates that each inflammasome preferentially localizes to the urothelium. Reprinted with permission from [19].

high-grade tumors, although the significance of that is unknown. They also saw an increase in NLRP3 gene expression in patients with non-malignant inflammatory lesions on biopsy compared to healthy controls. The group concluded that concurrent analysis of NLRP3 or NAIP expression with CK20 enhanced the sensitivity and specificity of detection of bladder cancer. Therefore, while the mechanism of NLRP3 and NLRC4 inflammasomes in the genesis or proliferation of bladder cancer is unknown, their expression is present and may serve as a potential diagnostic biomarker.

\section{Non-NLRP3 Inflammasomes in the Bladder and Their Potential Roles}

NLRP3 is the most studied inflammasome in the bladder and elsewhere. While most bladder pathology has been linked to this inflammasome, other inflam-
Table 2. Inflammasomes localized to the bladder urothelium and their potentially associated bladder pathologies

\begin{tabular}{lll}
\hline Inflammasome & $\begin{array}{l}\text { Bladder condition(s) } \\
\text { associated with inflammasome }\end{array}$ & $\begin{array}{l}\text { Potential bladder condition(s) } \\
\text { associated with inflammasome }\end{array}$ \\
\hline NLRP1 & UTI \\
NLRP3 & $\begin{array}{l}\text { cyclophosphamide-induced } \\
\text { hemorrhagic cystitis } \\
\text { BOO }\end{array}$ & \\
& UTI & \\
bladder cancer & \\
NLRP6 & & UTI \\
& & $\begin{array}{l}\text { bladder stone formation } \\
\text { radiation cystitis } \\
\text { bladder cancer }\end{array}$ \\
& & interstitial cystitis \\
NLRP7 & UTI \\
NLRP12 & & UTI \\
& & interstitial cystitis \\
NLRC4 & & UTI \\
AIM2 & bladder cancer & UTI \\
& &
\end{tabular}

Seven inflammasomes in the NLR and AIM receptor family have been localized to the bladder urothelium. This table lists the known and potentially associated bladder inflammation diseases mediated by the inflammasomes.

masomes may have potential roles as well. Indeed, many other NLRs that form inflammasomes, along with AIM2 which also forms an inflammasome, have been localized to the urothelia [95] (fig. 7) and thus may be important mediators in bladder inflammatory pathologies through unexplored mechanisms. As the RIG-I inflammasome has not been localized to the bladder urothelium, it was not included in the following section. Table 2 lists the inflammasome-forming PPRs that have been found in the bladder and their known and potential roles in the bladder, which will be discussed in more detail below.

\section{NLRP1 Inflammasome}

NLRP1 was the first inflammasome to be described [1] and it plays a role in prostate inflammation [94]. It differs mechanistically from NLRP3 by undergoing an autolytic proteolysis necessary for activation [114]. It has been implicated in the inflammatory response to Bacillus anthracis [115], but, importantly, it has also been found to respond to muramyl dipeptide, which is a common peptidoglycan in gram positive and negative bacteria [116]. Therefore, the NLRP1 inflammasome may play a role in mediating UTI responses.

\section{NLRP6 Inflammasome}

The NLRP6 inflammasome differs from NLRP3 by not only activating proinflammatory cytokines, but by also having the potential to directly downregulate the $\mathrm{NF}-\kappa \mathrm{B}$ and mitogen-activated protein kinase pathways 
[117, 118]. NLRP6 is best known for playing two distinct roles in the gut: regulating intestinal microbiota and maintaining the protective mucus layer by facilitating autophagy in intestinal goblet cells [119]. While no PAMP has been found to specifically activate NLRP6 [95], its roles in the intestine may reflect its potential role in the bladder, which is known to have both asymptomatic biotic flora [120, 121] and significant surface mucus [122]. Intriguingly, its potential role in regulating mucus may make it a useful therapeutic target since dysfunction of bladder surface mucins has been implicated in many bladder disorders including UTIs, calculus formation, radiation cystitis, carcinogenesis, and interstitial cystitis.

\section{NLRP7 Inflammasome}

Little is known about the mechanism of activation of NLRP7, but it has been shown to form an inflammasome in response to microbial acylated lipopeptides, common in bacteria such as pseudomonas, which is a prevalent UTI pathogen [123, 124]. Furthermore, NLRP7-produced IL-1 $\beta$ and IL-18 prevent replication of bacteria inside human macrophages [125]. While macrophages are very different from urothelial cells, NLRP7 may play a role in controlling intracellular bacterial communities known to cause chronic cystitis.

\section{NLRP12 Inflammasome}

Another poorly understood NLR family member, NLRP12, seems to depend on a functional type III secretion (T3S) system for its activation [126]. As gram-negative bacteria, such as pseudomonas, are known to invade host cells using a T3S system [127], the NLRP12 inflammasome may play a role in gram-negative UTI. NLRP12 may also be involved in bladder disease associated with idiopathic sterile bladder inflammation, such as interstitial cystitis, for NLRP12 mutations have been associated with hereditary periodic fever syndromes, another unprovoked, self-limited inflammatory attack mediated by IL$1 \beta[128,129]$.

\section{NLRC4 Inflammasome}

Even though it has been implicated as a biomarker in bladder cancer, the NLRC4 inflammasome is most commonly known to respond to macrophage invasion by gram-negative bacteria such as Salmonella typhimurium, Legionella pneumophila, and Pseudomonas aeruginosa [130-132]. Each of these bacteria send their virulence factors, such as flagellin and the inner-rod protein PrgJ, into the cell's cytoplasm through the bacterial T3S system [133]. These bacterial components are recognized in the cytosol by NAIPs, which then facilitate formation of the NLRC4 inflammasome. By drawing a comparison to its role in pulmonary pseudomonal infections [134], NLRC4 may be a central mediator in pseudomonal UTI. Furthermore, UPECs express aT3S system [135] and therefore may also interact with NLRC4. Finally, our lab has shown that placing flagellin, a well-established activator of NLRC4, in the lumen of the bladder activates caspase-1 activity [51] suggesting this system in the bladder is primed and ready to respond to invading bacteria.

\section{AIM2 Inflammasome}

Although AIM2 is not an NLR member, it does form an inflammasome and activate caspase-1. AIM2 is characterized by its Hin200 domains that bind to bacterial and viral double-stranded DNA to trigger inflammasome formation [14]. Therefore, the AIM2 inflammasome may respond to uropathogenic bacteria that release their DNA into the cytoplasm (such as through a T3S system or cytosolic bacteriolysis) or viruses that cause cystitis.

\section{Additional Bladder Disorders}

While inflammation is well understood to underlie bladder dysfunction in several common diseases, the role of the inflammasome as the central mediator has only recently been explored. In addition to the conditions just discussed, inflammasomes may be involved in other bladder pathologies like interstitial cystitis and diabetic bladder dysfunction, two common and debilitating diseases associated with bladder inflammation. There is also a potential role for inflammasomes in the inflammation caused by bladder stones. Indeed, monosodium urate is a well-known DAMP and a major component of bladder stones [136]. Our lab has shown that monosodium urate placed in the lumen of the bladder is sufficient to trigger inflammasome activation [51]. By understanding the role of each inflammasome in various pathological conditions, we may be able to target them with therapeutic agents to prevent these diseases and their symptoms.

\section{Potential Treatments}

As mentioned, our lab has used glyburide and anakinra, two FDA-approved medications, to inhibit the NLRP3 inflammasome and block the IL-1 receptor, respectively. Although glyburide is very useful experimentally, its hypoglycemic properties would probably limit 
widespread use in the general clinical population. Anakinra may be a more readily accepted anti-inflammasome medication, since it is already used for treating inflammatory diseases such as rheumatoid arthritis [137], but its current cost, side effect profile (including immunosuppression), and route of administration (subcutaneous) may limit its use as well. Besides these FDA-approved medications, the Chinese licorice Glycyrrhiza uralensis has been used for centuries as an anti-inflammatory treatment [138]. Recently, one of the active ingredients in this plant, isoliquirtigenin, has been found to be a naturally occurring NLRP3 inhibitor [139]. Not surprisingly, pharmaceutical companies are also developing a wide variety novel medications that target the NLRP3/ IL-1 $\beta$ pathway. These include small molecule inhibitors of NLRP3 such as AC-201 (TWi Biotechnology, Taiwan), MCC950 (Avistron, UK) and Parthenolide (Ashbury Biologicals, Canada) [140-142], caspase inhibitors such as Emricasan/IDN-6556 (Conatus Pharmaceuticals, USA) [143] and modified antibodies against IL-1 $\beta$ such as gevokizumab/XOMA 052 (Xoma Corporation, USA), HL 2351/GX P4, Handok, S. Korea) and Canakinumab/ Ilaris/ACZ885 (Novartis, Switzerland).

\section{Conclusion}

In both normal and pathological situations, the bladder is a hostile environment and source of many agents that activate inflammasomes to initiate inflammation. While the initial symptoms of inflammation that force a patient to seek a physician are typically irritative voiding patterns and feelings of urinary urgency, long-term or repetitive insults can lead to more dangerous and irreversible outcomes. Further explanation of the inflammasomes and their roles in urologic pathology will greatly enhance our understanding of urologic disease and provide possible therapeutic targets for intervention and management of the debilitating symptoms.

\section{Abbreviations}

AIM2 $=$ absent in melanoma 2

ASC $=$ apoptosis-associated speck-like protein containing a CARD

ATP $=$ adenosine triphosphate

$\mathrm{BOO}=$ bladder outlet obstruction

$\mathrm{BPH}=$ benign prostatic hyperplasia

CARD $=$ caspase recruitment domains

CK20 = cytokeratin 20

DAMP = danger (or damage) associated molecular pattern

FADD $=$ Fas-associated protein with death domain

FDA $=$ Food and Drug Administration

GBS $=$ group B streptococcus

HMGB 1= high-mobility group box 1

IGF $=$ insulin-like growth factor

LPS $=$ lipopolysaccharide

LRR = leucine-rich repeat

MAVS = mitochondrial antiviral signaling protein

MESNA = 2-mercaptoethane sulfonate sodium

$\mathrm{MSU}=$ monosodium urate

NACHT = nucleotide-binding and oligomerization

NAIP = NLR family apoptosis inhibiting protein

NEK = NIMA-related kinase

NIMA $=$ never in mitosis gene a

NLR = NOD-like receptors

NLRP3 = NACHT, LRR and PYD domains-containing protein

NOD = nucleotide-binding and oligomerization domain

PAMP $=$ pathogen-associated molecular pattern

$\mathrm{PRR}=$ pattern recognition receptor

PYD = pyrin domain

RIG-1 = retinoic acid-inducible gene-I

RIPK1 = receptor-interacting protein kinase 1

ROS $=$ reactive oxygen species

$\mathrm{TIR}=$ toll/interleukin -1 receptor

TLR $=$ toll-like receptor

TNFR $=$ tumor necrosis factor receptor

TRIF = TIR-domain-containing adapter-inducing interferon- $\beta$ toll/interleukin-1 receptor-containing adapter-inducing interferon- $\beta$

$\mathrm{T} 3 \mathrm{~S}=$ type III secretion

UPEC = uropathogenic Escherichia coli

$\mathrm{UTI}=$ urinary tract infection

\section{References}

1 Martinon F, Burns K, Tschopp J: The inflammasome: a molecular platform triggering activation of inflammatory caspases and processing of proIL-beta. Mol Cell 2002;10: 417-426.

2 Purves JT, Hughes FM Jr: Inflammasomes in the urinary tract: a disease-based review. Am J Physiol Renal Physiol 2016;311:F653F662.
3 Hamilton C, Tan L, Miethke T, Anand PK: Immunity to uropathogens: the emerging roles of inflammasomes. Nat Rev Urol 2017; 14:284-295.

4 Mogensen TH: Pathogen recognition and inflammatory signaling in innate immune defenses. Clin Microbiol Rev 2009;22:240 273
5 Lamkanfi M, Dixit VM: Modulation of inflammasome pathways by bacterial and viral pathogens. J Immunol 2011;187:597-602.

6 Takeuchi O, Akira S: Pattern recognition receptors and inflammation. Cell 2010;140: 805-820. 
7 Lappas M: NOD1 and NOD2 regulate proinflammatory and prolabor mediators in human fetal membranes and myometrium via nuclear factor-kappa B. Biol Reproduct 2013; 89:14.

8 Wilmanski JM, Petnicki-Ocwieja T, Kobayashi KS: NLR proteins: integral members of innate immunity and mediators of inflammatory diseases. J Leukoc Biol 2008;83:1330.

9 Kayagaki N, Stowe IB, Lee BL, O'Rourke K, Anderson K, Warming S, Cuellar T, Haley B, Roose-Girma M, Phung QT, Liu PS, Lill JR, Li H, Wu J, Kummerfeld S, Zhang J, Lee WP, Snipas SJ, Salvesen GS, Morris LX, Fitzgerald L, Zhang Y, Bertram EM, Goodnow CC, Dixit VM: Caspase-11 cleaves gasdermin D for non-canonical inflammasome signalling. Nature 2015;526:666-671.

10 Shi J, Zhao Y, Wang K, Shi X, Wang Y, Huang H, Zhuang Y, Cai T, Wang F, Shao F: Cleavage of GSDMD by inflammatory caspases determines pyroptotic cell death. Nature 2015;526:660-665.

11 Lamkanfi M, Dixit VM: Mechanisms and functions of inflammasomes. Cell 2014;157: 1013-1022.

12 Fink SL, Cookson BT: Caspase-1-dependent pore formation during pyroptosis leads to osmotic lysis of infected host macrophages. Cell Microbiol 2006;8:1812-1825.

13 Poeck H, Bscheider M, Gross O, Finger K, Roth S, Rebsamen M, Hannesschläger N, Schlee M, Rothenfusser S, Barchet W, Kato H, Akira S, Inoue S, Endres S, Peschel C, Hartmann G, Hornung V, Ruland J: Recognition of RNA virus by RIG-I results in activation of CARD9 and inflammasome signaling for interleukin 1 beta production. Nat Immunol 2010;11:63-69.

14 Hornung V, Ablasser A, Charrel-Dennis M, Bauernfeind F, Horvath G, Caffrey DR, Latz E, Fitzgerald KA: AIM2 recognizes cytosolic dsDNA and forms a caspase-1-activating inflammasome with ASC. Nature 2009; 458:514-518.

15 Bauernfeind FG, Horvath G, Stutz A, Alnemri ES, MacDonald K, Speert D, Fernandes-Alnemri T, Wu J, Monks BG, Fitzgerald KA, Hornung V, Latz E: Cutting edge: NF-kap$\mathrm{paB}$ activating pattern recognition and cytokine receptors license NLRP3 inflammasome activation by regulating NLRP3 expression. $\mathrm{J}$ Immunol 2009;183:787-791.

16 Mariathasan S, Weiss DS, Newton K, McBride J, O'Rourke K, Roose-Girma M, Lee WP, Weinrauch Y, Monack DM, Dixit VM: Cryopyrin activates the inflammasome in response to toxins and ATP. Nature 2006;440: 228-232.

17 Martinon F, Petrilli V, Mayor A, Tardivel A, Tschopp J: Gout-associated uric acid crystals activate the NALP3 inflammasome. Nature 2006;440:237-241.
18 Kummer JA, Broekhuizen R, Everett H, Agostini L, Kuijk L, Martinon F, van Bruggen R, Tschopp J: Inflammasome components NALP 1 and 3 show distinct but separate expression profiles in human tissues suggesting a site-specific role in the inflammatory response. J Histochem Cytochem 2007;55: 443-452.

19 Hughes FM Jr, Turner DP, Todd Purves J: The potential repertoire of the innate immune system in the bladder: expression of pattern recognition receptors in the rat bladder and a rat urothelial cell line (MYP3 cells). Int Urol Nephrol 2015;47:1953-1964.

20 Guo H, Callaway JB, Ting JP: Inflammasomes: mechanism of action, role in disease, and therapeutics. Nat Med 2015;21: 677-687.

21 Sutterwala FS, Haasken S, Cassel SL: Mechanism of NLRP3 inflammasome activation. Ann N Y Acad Sci 2014;1319:82-95.

22 Wen H, Miao EA, Ting JP: Mechanisms of NOD-like receptor-associated inflammasome activation. Immunity 2013;39:432-441.

23 Gaidt MM, Hornung V: Alternative inflammasome activation enables IL-1beta release from living cells. Curr Opin Immunol 2016; 44:7-13.

24 He Y, Hara H, Nunez G: Mechanism and regulation of NLRP3 inflammasome activation. Trends Biochem Sci 2016;41:1012-1021.

25 Gaidt MM, Ebert TS, Chauhan D, Schmidt T, Schmid-Burgk JL, Rapino F, Robertson AA, Cooper MA, Graf T, Hornung V: Human monocytes engage an alternative inflammasome pathway. Immunity 2016;44:833846.

26 Patel MN, Carroll RG, Galvan-Pena S, Mills EL, Olden R, Triantafilou M, Wolf AI, Bryant CE, Triantafilou K, Masters SL: Inflammasome priming in sterile inflammatory disease. Trends Mol Med 2017;23:165-180.

27 Franchi L, Eigenbrod T, Nunez G: Cutting edge: TNF-alpha mediates sensitization to ATP and silica via the NLRP3 inflammasome in the absence of microbial stimulation. J Immunol 2009;183:792-796.

28 Py BF, Kim MS, Vakifahmetoglu-Norberg $\mathrm{H}$, Yuan J: Deubiquitination of NLRP3 by BRCC3 critically regulates inflammasome activity. Mol Cell 2013;49:331-338.

29 Juliana C, Fernandes-Alnemri T, Kang S, Farias A, Qin F, Alnemri ES: Non-transcriptional priming and deubiquitination regulate NLRP3 inflammasome activation. J Biol Chem 2012;287:36617-36622.

30 Dostert C, Petrilli V, Van Bruggen R, Steele C, Mossman BT, Tschopp J: Innate immune activation through Nalp3 inflammasome sensing of asbestos and silica. Science 2008; 320:674-677.

31 Munoz-Planillo R, Kuffa P, Martinez-Colon G, Smith BL, Rajendiran TM, Nunez G: $\mathrm{K}^{+}$efflux is the common trigger of NLRP3 inflammasome activation by bacterial toxins and particulate matter. Immunity 2013; 38:1142-1153.
32 Harijith A, Ebenezer DL, Natarajan V: Reactive oxygen species at the crossroads of inflammasome and inflammation. Front Physiol 2014;5:352.

33 Lee GS, Subramanian N, Kim AI, Aksentijevich I, Goldbach-Mansky R, Sacks DB, Germain RN, Kastner DL, Chae JJ: The calcium-sensing receptor regulates the NLRP3 inflammasome through $\mathrm{Ca}^{2+}$ and cAMP. Nature 2012;492:123-127.

34 Murakami T, Ockinger J, Yu J, Byles V, McColl A, Hofer AM, Horng T: Critical role for calcium mobilization in activation of the NLRP3 inflammasome. Proc Natl Acad Sci USA 2012;109:11282-11287.

35 Rossol M, Pierer M, Raulien N, Quandt D, Meusch U, Rothe K, Schubert K, Schöneberg T, Schaefer M, Krügel U, Smajilovic S, Bräuner-Osborne $\mathrm{H}$, Baerwald $\mathrm{C}$, Wagner $\mathrm{U}$ : Extracellular $\mathrm{Ca}^{2+}$ is a danger signal activating the NLRP3 inflammasome through $\mathrm{G}$ protein-coupled calcium sensing receptors. Nat Commun 2012;3:1329.

36 Katsnelson MA, Rucker LG, Russo HM, Dubyak GR: $\mathrm{K}^{+}$efflux agonists induce NLRP3 inflammasome activation independently of $\mathrm{Ca}^{2+}$ signaling. J Immunol 2015;194:39373952.

37 Franchi L, Kanneganti TD, Dubyak GR, Nunez G: Differential requirement of P2X7 receptor and intracellular $\mathrm{K}^{+}$for caspase-1 activation induced by intracellular and extracellular bacteria. J Biol Chem 2007;282: 18810-18818.

38 Petrilli V, Papin S, Dostert C, Mayor A, Martinon F, Tschopp J: Activation of the NALP3 inflammasome is triggered by low intracellular potassium concentration. Cell Death Differ 2007;14:1583-1589.

39 Bortner CD, Hughes FM Jr, Cidlowski JA: A primary role for $\mathrm{K}^{+}$and $\mathrm{Na}^{+}$efflux in the activation of apoptosis. J Biol Chem 1997; 272:32436-32442.

40 Hughes FM Jr, Bortner CD, Purdy GD, Cidlowski JA: Intracellular $\mathrm{K}^{+}$suppresses the activation of apoptosis in lymphocytes. J Biol Chem 1997;272:30567-30576.

41 Bortner CD, Cidlowski JA: Cell shrinkage and monovalent cation fluxes: role in apoptosis. Arch Biochem Biophys 2007;462:176188.

42 He Y, Zeng MY, Yang D, Motro B, Nunez G: NEK7 is an essential mediator of NLRP3 activation downstream of potassium efflux. Nature 2016;530:354-357.

43 Shi H, Wang Y, Li X, Zhan X, Tang M, Fina M, Su L, Pratt D, Bu CH, Hildebrand S, Lyon S, Scott L, Quan J, Sun Q, Russell J, Arnett S, Jurek P, Chen D, Kravchenko VV, Mathison JC, Moresco EM, Monson NL, Ulevitch RJ, Beutler B: NLRP3 activation and mitosis are mutually exclusive events coordinated by NEK7, a new inflammasome component. Nat Immunol 2016;17:250-258. 
44 Ding J, Wang K, Liu W, She Y, Sun Q, Shi J, Sun H, Wang DC, Shao F: Pore-forming activity and structural autoinhibition of the gasdermin family. Nature 2016;535:111116.

45 Sborgi L, Ruhl S, Mulvihill E, Pipercevic J, Heilig R, Stahlberg H, Farady CJ, Müller DJ, Broz P, Hiller S: GSDMD membrane pore formation constitutes the mechanism of pyroptotic cell death. EMBO J 2016;35:1766-1778.

46 Aglietti RA, Estevez A, Gupta A, Ramirez MG, Liu PS, Kayagaki N, Ciferri C, Dixit VM, Dueber EC: GsdmD p30 elicited by caspase-11 during pyroptosis forms pores in membranes. Proc Natl Acad Sci USA 2016;113:7858-7863.

47 Kayagaki N, Warming S, Lamkanfi M, Vande Walle L, Louie S, Dong J, Newton K, Qu Y, Liu J, Heldens S, Zhang J, Lee WP, Roose-Girma M, Dixit VM: Non-canonical inflammasome activation targets caspase-11. Nature 2011;479:117-121.

48 Shi J, Zhao Y, Wang Y, Gao W, Ding J, Li P, $\mathrm{Hu}$ L, Shao F: Inflammatory caspases are innate immune receptors for intracellular LPS. Nature 2014;514:187-192.

49 Wang S, Miura M, Jung YK, Zhu H, Li E, Yuan J: Murine caspase-11, an ICE-interacting protease, is essential for the activation of ICE. Cell 1998;92:501-509.

50 Gross CJ, Mishra R, Schneider KS, Médard G, Wettmarshausen J, Dittlein DC, Shi H, Gorka O, Koenig PA, Fromm S, Magnani G, ikovi T, Hartjes L, Smollich J, Robertson AAB7, Cooper MA, Schmidt-Supprian M, Schuster M, Schroder K, Broz P, Traidl-Hoffmann C4, Beutler B, Kuster B, Ruland J, Schneider S, Perocchi F, Groß O: $\mathrm{K}^{+}$efflux-independent NLRP3 inflammasome activation by small molecules targeting mitochondria. Immunity 2016;45:761-773.

51 Hughes FM Jr, Vivar NP, Kennis JG, Pratt-Thomas JD, Lowe DW, Shaner BE, Nietert PJ, Spruill LS, Purves JT: Inflammasomes are important mediators of cyclophosphamide-induced bladder inflammation. Am J Physiol Renal physiol 2014;306:F299-308.

52 Smaldone MC, Vodovotz Y, Tyagi V, Barclay D, Philips BJ, Yoshimura N, Chancellor MB, Tyagi P: Multiplex analysis of urinary cytokine levels in rat model of cyclophosphamide-induced cystitis. Urology 2009;73: 421-426.

53 Leite CA, Alencar VT, Melo DL, Mota JM, Melo PH, Mourão LT, Wong DV, Magalhães PJ, Santos AA, Brito GA, Lima-Júnior RC, Cunha FQ, Ribeiro RA: Target inhibition of IL-1 receptor prevents Ifosfamide induced hemorrhagic cystitis in mice. J Urol 2015; 194:1777-1786.
54 Ribeiro RA, Freitas HC, Campos MC, Santos CC, Figueiredo FC, Brito GA, Cunha FQ: Tumor necrosis factor-alpha and interleukin-1beta mediate the production of nitric oxide involved in the pathogenesis of ifosfamide induced hemorrhagic cystitis in mice. J Urol 2002;167:2229-2234.

55 Batista CK, Brito GA, Souza ML, Leitao BT, Cunha FQ, Ribeiro RA: A model of hemorrhagic cystitis induced with acrolein in mice. Braz J Med Biol Res 2006;39:1475-1481.

56 Lamkanfi M, Mueller JL, Vitari AC, Misaghi S, Fedorova A, Deshayes K, Lee WP, Hoffman HM, Dixit VM: Glyburide inhibits the Cryopyrin/Nalp3 inflammasome. J Cell Biol 2009;187:61-70.

57 Haldar S, Dru C, Choudhury D, Mishra R, Fernandez A, Biondi S, Liu Z, Shimada K, Arditi M, Bhowmick NA: Inflammation and pyroptosis mediate muscle expansion in an interleukin-1beta (IL-1beta)-dependent manner. J Biological Chemistry 2015;290:6574-6583.

58 Metcalfe PD, Wang J, Jiao H, Huang Y, Hori K, Moore RB, Tredget EE: Bladder outlet obstruction: progression from inflammation to fibrosis. BJU Int 2010;106:1686-1694.

59 Oka M, Fukui T, Ueda M, Tagaya M, Oyama T, Tanaka M: Suppression of bladder oxidative stress and inflammation by a phytotherapeutic agent in a rat model of partial bladder outlet obstruction. J Urol 2009; 182:382-390.

60 Deveaud CM, Macarak EJ, Kucich U, Ewalt DH, Abrams WR, Howard PS: Molecular analysis of collagens in bladder fibrosis. $\mathrm{J}$ Urol 1998;160:1518-1527.

61 Hughes FM, Govada V, Sexton SJ, Purves $\mathrm{J}$ : Fibrosis in the bladder in response to outlet obstruction is triggered through the NLRP3 inflammasome and the production of IL-1 $\beta$. Transl Androl Urol 2016;5(Suppl 2):AB279.

62 Hughes FM Jr, Hill HM, Wood CM, Edmondson AT, Dumas A, Foo WC, Oelsen JM, Rac G, Purves JT: The NLRP3 inflammasome mediates inflammation produced by bladder outlet obstruction. J Urol 2016;195:1598-1605.

63 Lutolf R, Hughes FM, Purves J: NLRP3/ IL-1 $\beta$ mediates denervation during bladder outlet obstruction in rats. Transl Androl Urol 2016;5(Suppl 2):AB298.

64 Kanno Y, Mitsui T, Kitta T, Moriya K, Tsukiyama T, Hatakeyama S, Nonomura K: The inflammatory cytokine IL-1beta is involved in bladder remodeling after bladder outlet obstruction in mice. Neurourol Urodyn 2016; 35:3773-3778.

65 Abderrazak A, Syrovets T, Couchie D, El Hadri K, Friguet B, Simmet T, Rouis M: NLRP3 inflammasome: From a danger signal sensor to a regulatory node of oxidative stress and inflammatory diseases. Redox Biol 2015;4:296-307.
66 Yamaguchi O, Nomiya M, Andersson KE: Functional consequences of chronic bladder ischemia. Neurourol Urodyn 2014;33:54-58.

67 Gombault A, Baron L, Couillin I: ATP release and purinergic signaling in NLRP3 inflammasome activation. Front Immunol 2012;3: 414.

68 Olsen SM, Stover JD, Nagatomi J: Examining the role of mechanosensitive ion channels in pressure mechanotransduction in rat bladder urothelial cells. Ann Biomed Eng 2011; 39:688-697.

69 Dunton CL, Hughes FM, Purves J, Nagatomi J: In vitro evaluation of hydrostatic pressure on ATP release and Caspase-1 activation in rat urothelial cells. Transl Androl Urol 1916; 5(Suppl 2):AB276.

70 Chen S, Peng C, Wei X, Luo D, Lin Y, Yang T, Jin X, Gong L, Li H, Wang K: Simulated physiological stretch increases expression of extracellular matrix proteins in human bladder smooth muscle cells via integrin alpha4/alphav-FAK-ERK1/2 signaling pathway. World J Urology 2017;35:1247-1254.

71 Dunning-Davies BM, Fry CH, Mansour D, Ferguson DR: The regulation of ATP release from the urothelium by adenosine and transepithelial potential. BJU Int 2013;111:505-513.

72 Mochizuki T, Sokabe T, Araki I, Fujishita K, Shibasaki K, Uchida K, Naruse K, Koizumi S, Takeda M, Tominaga M: The TRPV4 cation channel mediates stretchevoked $\mathrm{Ca}^{2+}$ influx and ATP release in primary urothelial cell cultures. J Biol Chem 2009;284:21257-21264.

73 Ochodnicky P, Michel MB, Butter JJ, Seth J, Panicker JN, Michel MC: Bradykinin modulates spontaneous nerve growth factor production and stretch-induced ATP release in human urothelium. Pharmacol Res 2013;70: 147-154.

74 Young JS, Matharu R, Carew MA, Fry CH: Inhibition of stretching-evoked ATP release from bladder mucosa by anticholinergic agents. BJU Int 2012;110:E397-401.

75 Moro C, Uchiyama J, Chess-Williams R: Urothelial/lamina propria spontaneous activity and the role of M3 muscarinic receptors in mediating rate responses to stretch and carbachol. Urology 2011;78:1442e915.

76 Cheng Y, Mansfield KJ, Sandow SL, Sadananda P, Burcher E, Moore KH: Porcine bladder urothelial, myofibroblast, and detrusor muscle cells: characterization and ATP release. Front Pharmacol 2011;2:27.

77 Ferguson DR, Kennedy I, Burton TJ: ATP is released from rabbit urinary bladder epithelial cells by hydrostatic pressure changes-a possible sensory mechanism? J Physiol 1997; 505( Pt 2):503-511. 
78 Beckel JM, Birder LA: Differential expression and function of nicotinic acetylcholine receptors in the urinary bladder epithelium of the rat. J Physiology 2012;590:14651480.

79 McLatchie LM, Young JS, Fry CH: Regulation of $\mathrm{ACh}$ release from guinea pig bladder urothelial cells: potential role in bladder filling sensations. Br J Pharmacol 2014;171: 3394-3403.

80 Sun Y, Chai TC: Augmented extracellular ATP signaling in bladder urothelial cells from patients with interstitial cystitis. Am J Physiol Cell physiol 2006;290:C27-34.

81 Bugyei-Twum A, Abadeh A, Thai K, Zhang Y, Mitchell M, Kabir G, Connelly KA: Suppression of NLRP3 inflammasome activation ameliorates chronic kidney disease-induced cardiac fibrosis and diastolic dysfunction. Sci Rep 2016;6:39551.

82 Sayan M, Mossman BT: The NLRP3 inflammasome in pathogenic particle and fibre-associated lung inflammation and diseases. Part Fibre Toxicol 2016;13:51.

83 Gong W, Mao S, Yu J, Song J, Jia Z, Huang S, Zhang A: NLRP3 deletion protects against renal fibrosis and attenuates mitochondrial abnormality in mouse with $5 / 6$ nephrectomy. Am J Physiol Renal Physiol 2016;310: F1081-1088.

84 Gasse P, Riteau N, Vacher R, Michel ML, Fautrel A, di Padova F, Fick L, Charron S, Lagente V, Eberl G, Le Bert M, Quesniaux VF, Huaux F, Leite-de-Moraes M, Ryffel B, Couillin I: IL-1 and IL-23 mediate early IL17A production in pulmonary inflammation leading to late fibrosis. PloS One 2011;6: e23185.

85 Sexton SJ, Hughes FM, Purves JT: Fibrosis in the bladder in response to outlet obstruction is triggered through the NLRP3 inflammasome and the production of IL-1 $\beta$. North Carolina Urology Association, Durham, ND 2016.

86 Harrison SC, Hunnam GR, Farman P, Ferguson DR, Doyle PT: Bladder instability and denervation in patients with bladder outflow obstruction. $\mathrm{Br} \mathrm{J}$ Urol 1987;60:519-522.

87 Speakman MJ, Brading AF, Gilpin CJ, Dixon JS, Gilpin SA, Gosling JA: Bladder outflow obstruction--a cause of denervation supersensitivity. J Urol 1987;138:14611466.

88 de Jongh R, Dambros M, Haenen GR, den Hartog GJ, Bast A, van Kerrebroeck PE, van Koeveringe GA: Partial bladder outlet obstruction reduces the tissue antioxidant capacity and muscle nerve density of the guinea pig bladder. Neurourol Urodyn 2009;28:461-467.

89 Nyirady P, Thiruchelvam N, Fry CH, Godley ML, Winyard PJ, Peebles DM, Woolf AS, Cuckow PM: Effects of in utero bladder outflow obstruction on fetal sheep detrusor contractility, compliance and innervation. J Urol 2002;168:1615-1620.
90 Levin RM, Levin SS, Zhao Y, Buttyan R: Cellular and molecular aspects of bladder hypertrophy. Eur Urol 1997;32(Suppl 1):15-21.

91 Barendrecht MM, Chichester P, Michel MC, Levin RM: Effect of short-term outlet obstruction on rat bladder nerve density and contractility. Auton Autacoid Pharmacol 2007;27:47-53.

92 Nomiya M, Andersson KE, Yamaguchi O: Chronic bladder ischemia and oxidative stress: new pharmacotherapeutic targets for lower urinary tract symptoms. Int $\mathrm{J}$ Urol 2015;22:40-46.

93 Chughtai B, Lee R, Te A, Kaplan S: Role of inflammation in benign prostatic hyperplasia. Rev Urol 2011;13:147-150.

94 Kashyap M, Pore S, Wang Z, Gingrich J, Yoshimura N, Tyagi P: Inflammasomes are important mediators of prostatic inflammation associated with BPH. J Inflamm (Lond) 2015;12:37.

95 Hughes FM Jr, Turner DP, Todd Purves J: The potential repertoire of the innate immune system in the bladder: expression of pattern recognition receptors in the rat bladder and a rat urothelial cell line (MYP3 cells). Int Urol Nephrol 2015;47:19531964.

96 Agace W, Hedges S, Andersson U, Andersson J, Ceska M, Svanborg C: Selective cytokine production by epithelial cells following exposure to Escherichia coli. Infect Immun 1993;61:602-609.

97 Foxman B: Epidemiology of urinary tract infections: incidence, morbidity, and economic costs. Am J Med 2002;113(Suppl 1A):5S-13S

98 Hughes FM Jr, Kennis JG, Youssef MN, Lowe DW, Shaner BE, Purves JT: The NACHT, LRR and PYD domains-containing protein 3 (NLRP3) inflammasome mediates inflammation and voiding dysfunction in a lipopolysaccharide-induced rat model of cystitis. J Clin Cell Immunol 2016;7:396.

99 Nagamatsu K, Hannan TJ, Guest RL, Kostakioti M, Hadjifrangiskou M, Binkley J, Dodson K, Raivio TL, Hultgren SJ: Dysregulation of Escherichia coli alpha-hemolysin expression alters the course of acute and persistent urinary tract infection. Proc Natl Acad Sci USA 2015;112:E871-880.

100 Schaale K, Peters KM, Murthy AM, Fritzsche AK, Phan MD, Totsika M, Robertson AA, Nichols KB, Cooper MA, Stacey KJ, Ulett GC, Schroder K, Schembri MA, Sweet MJ: Strain- and host species-specific inflammasome activation, IL-1beta release, and cell death in macrophages infected with uropathogenic Escherichia coli. Mucosal Immunol 2016;9:124-136.
101 Waldhuber A, Puthia M, Wieser A, Cirl C, Dürr S, Neumann-Pfeifer S, Albrecht S, Römmler F, Müller T, Zheng Y, Schubert S, Groß O, Svanborg C, Miethke T: Uropathogenic Escherichia coli strain CFT073 disrupts NLRP3 inflammasome activation. J Clin Invest 2016;126:2425-2436.

102 Schubert S, Norenberg D, Clermont O, Magistro G, Wieser A, Romann E, Hoffmann C, Weinert K, Denamur E: Prevalence and phylogenetic history of the TcpC virulence determinant in Escherichia coli. Int J Med Microbiol 2010;300:429-434.

103 Costa A, Gupta R, Signorino G, Malara A, Cardile F, Biondo C, Midiri A, Galbo R, Trieu-Cuot P, Papasergi S, Teti G, Henneke P, Mancuso G, Golenbock DT, Beninati C: Activation of the NLRP3 inflammasome by group B streptococci. J Immunol 2012;188: 1953-1960.

104 Ulett GC, Webb RI, Ulett KB, Cui X, Benjamin WH, Crowley M, Schembri MA: Group B Streptococcus (GBS) urinary tract infection involves binding of GBS to bladder uroepithelium and potent but GBS-specific induction of interleukin 1alpha. J Infect Dis 2010;201:866-870.

105 Gupta R, Ghosh S, Monks B, DeOliveira RB, Tzeng TC, Kalantari P, Nandy A, Bhattacharjee B, Chan J, Ferreira F, Rathinam $\mathrm{V}$, Sharma S, Lien E, Silverman N, Fitzgerald K, Firon A, Trieu-Cuot P, Henneke P, Golenbock DT: RNA and beta-hemolysin of group B Streptococcus induce interleukin-1beta (IL-1beta) by activating NLRP3 inflammasomes in mouse macrophages. $\mathrm{J}$ Biol Chem 2014;289:13701-13705.

106 Kanneganti TD, Ozoren N, Body-Malapel M, Amer A, Park JH, Franchi L, Whitfield J, Barchet W, Colonna M, Vandenabeele P, Bertin J, Coyle A, Grant EP, Akira S, Núñez G: Bacterial RNA and small antiviral compounds activate caspase-1 through cryopyrin/Nalp3. Nature 2006;440:233-236.

107 Franchi L, Eigenbrod T, Munoz-Planillo R, Muñoz-Planillo R, Ozkurede U, Kim YG, Arindam C, Gale M Jr, Silverman RH, Colonna M, Akira S, Núñez G: Cytosolic double-stranded RNA activates the NLRP3 inflammasome via MAVS-induced membrane permeabilization and $\mathrm{K}^{+}$efflux. $\mathrm{J}$ Immunol 2014;193:4214-4222.

108 Biondo C, Mancuso G, Midiri A, Signorino G, Domina M, Lanza Cariccio V, Mohammadi N, Venza M, Venza I, Teti G, Beninati C: The interleukin-1beta/CXCL1/2/neutrophil axis mediates host protection against group B streptococcal infection. Infect Immunity 2014;82:4508-4517.

109 Verma D, Bivik C, Farahani E, Synnerstad I, Fredrikson M, Enerbäck C, Rosdahl I, Söderkvist P: Inflammasome polymorphisms confer susceptibility to sporadic malignant melanoma. Pigment Cell Melanoma Res 2012;25:506-513. 
110 Voronov E, Dotan S, Krelin Y, Song X, Elkabets M, Carmi Y, Rider P, Idan Cohen, Romzova M, Kaplanov I, Apte RN: Unique versus redundant functions of IL-1alpha and IL-1beta in the tumor microenvironment. Front Immunol 2013;4:177.

111 Ungerback J, Belenki D, Jawad ul-Hassan A, Fredrikson M, Fransén K, Elander N, Verma D, Söderkvist P: Genetic variation and alterations of genes involved in NFkappaB/TNFAIP3- and NLRP3-inflammasome signaling affect susceptibility and outcome of colorectal cancer. Carcinogenesis 2012; 33:2126-2134.

112 Poli G, Brancorsini S, Cochetti G, Barillaro F, Egidi MG, Mearini E: Expression of inflammasome-related genes in bladder cancer and their association with cytokeratin 20 messenger RNA. Urol Oncol 2015;33: $505 \mathrm{e} 1-7$.

113 Miettinen M: Keratin 20: immunohistochemical marker for gastrointestinal, urothelial, and Merkel cell carcinomas. Mod Pathol 1995;8:384-388.

114 Finger JN, Lich JD, Dare LC, Cook MN, Brown KK, Duraiswami C, Bertin J, Gough PJ: Autolytic proteolysis within the function to find domain (FIIND) is required for NLRP1 inflammasome activity. J Biol Chem 2012;287:25030-25037.

115 Boyden ED, Dietrich WF: Nalp1b controls mouse macrophage susceptibility to anthrax lethal toxin. Nat Genet 2006;38:240-244.

116 Faustin B, Lartigue L, Bruey JM, Luciano F, Sergienko E, Bailly-Maitre B, Volkmann N, Hanein D, Rouiller I, Reed JC: Reconstituted NALP1 inflammasome reveals twostep mechanism of caspase-1 activation. Mol Cell 2007;25:713-724.

117 Grenier JM, Wang L, Manji GA, Huang WJ, Al-Garawi A, Kelly R, Carlson A, Merriam S, Lora JM, Briskin M, DiStefano PS, Bertin J: Functional screening of five PYPAF family members identifies PYPAF5 as a novel regulator of NF-kappaB and caspase-1. FEBS Lett 2002;530:73-78.

118 Anand PK, Malireddi RK, Lukens JR, Vogel P, Bertin J, Lamkanfi M, Kanneganti TD: NLRP6 negatively regulates innate immunity and host defence against bacterial pathogens. Nature 2012;488:389-393.

119 Wlodarska M, Thaiss CA, Nowarski R, Henao-Mejia J, Zhang JP, Brown EM, Frankel G, Levy M, Katz MN, Philbrick WM, Elinav E, Finlay BB, Flavell RA: NLRP6 inflammasome orchestrates the colonic host-microbial interface by regulating goblet cell mucus secretion. Cell 2014;156: 1045-1059.

120 Hilt EE, McKinley K, Pearce MM, Rosenfeld AB, Zilliox MJ, Mueller ER, Brubaker L, Gai X, Wolfe AJ, Schreckenberger PC: Urine is not sterile: use of enhanced urine culture techniques to detect resident bacterial flora in the adult female bladder. J Clin Microbiol 2014;52:871-876.
121 Xu W, Yang L, Lee P, Huang WC, Nossa C, Ma Y, Deng FM, Zhou M, Melamed J, Pei $\mathrm{Z}$ : Mini-review: perspective of the microbiome in the pathogenesis of urothelial carcinoma. Am J Clin Exp Urol 2014;2:57-61.

122 Parsons CL: The role of the urinary epithelium in the pathogenesis of interstitial cystitis/prostatitis/urethritis. Urology 2007;69: 9-16.

123 Sanchez-Gomez S, Ferrer-Espada R, Stewart PS, Pitts B, Lohner K, Martinez de Tejada G: Antimicrobial activity of synthetic cationic peptides and lipopeptides derived from human lactoferricin against Pseudomonas aeruginosa planktonic cultures and biofilms. BMC Microbiol 2015;15:137.

124 Mittal R, Aggarwal S, Sharma S, Chhibber S, Harjai K: Urinary tract infections caused by Pseudomonas aeruginosa: a minireview. J Infect Public Health 2009;2:101-111.

125 Khare S, Dorfleutner A, Bryan NB, Yun C, Radian AD, de Almeida L, Rojanasakul Y, Stehlik C: An NLRP7-containing inflammasome mediates recognition of microbial lipopeptides in human macrophages. Immunity 2012;36:464-476.

126 Vladimer GI, Weng D, Paquette SW, Vanaja SK, Rathinam VA, Aune MH, Conlon JE, Burbage JJ, Proulx MK, Liu Q, Reed G, Mecsas JC, Iwakura Y, Bertin J, Goguen JD, Fitzgerald KA, Lien E: The NLRP12 inflammasome recognizes Yersinia pestis. Immunity 2012;37:96-107.

127 Sato H, Frank DW: Multi-functional characteristics of the Pseudomonas aeruginosa type III needle-tip protein, PcrV; comparison to orthologs in other Gram-negative bacteria. Front Microbiol 2011;2:142.

128 Jeru I, Duquesnoy P, Fernandes-Alnemri T, Cochet E, Yu JW, Lackmy-Port-Lis M, Grimprel E, Landman-Parker J, Hentgen V, Marlin S, McElreavey K, Sarkisian T, Grateau G, Alnemri ES, Amselem S: Mutations in NALP12 cause hereditary periodic fever syndromes. Proc Natl Acad Sci U S A 2008; 105:1614-1619.

129 Rigante D, Frediani B, Cantarini L: A Comprehensive overview of the hereditary periodic fever syndromes. Clin Rev Allergy Immunol 2016:1-8.

130 Mariathasan S, Newton K, Monack DM, Vucic D, French DM, Lee WP, RooseGirma M, Erickson S, Dixit VM: Differential activation of the inflammasome by caspase-1 adaptors ASC and Ipaf. Nature 2004:430:213-218.

131 Zamboni DS, Kobayashi KS, Kohlsdorf T, Ogura Y, Long EM, Vance RE, Kuida K, Mariathasan S, Dixit VM, Flavell RA, Dietrich WF, Roy CR: The Bircle cytosolic pattern-recognition receptor contributes to the detection and control of Legionella pneumophila infection. Nat Immunol 2006; 7: 318-325.
132 Miao EA, Ernst RK, Dors M, Mao DP, Aderem A: Pseudomonas aeruginosa activates caspase 1 through Ipaf. Proc Natl Acad Sci USA 2008;105:2562-2567.

133 Miao EA, Mao DP, Yudkovsky N, Bonneau R, Lorang CG, Warren SE, Leaf IA, Aderem A: Innate immune detection of the type III secretion apparatus through the NLRC4 inflammasome. Proc Natl Acad Sci USA 2010;107:3076-3080.

134 Sutterwala FS, Mijares LA, Li L, Ogura Y, Kazmierczak BI, Flavell RA: Immune recognition of Pseudomonas aeruginosa mediated by the IPAF/NLRC4 inflammasome. J Exp Med 2007;204:3235-3245.

135 Miyazaki J, Ba-Thein W, Kumao T, Akaza $\mathrm{H}$, Hayashi $\mathrm{H}$ : Identification of a type III secretion system in uropathogenic Escherichia coli. FEMS Microbiol Lett 2002;212: 221-228.

136 Miano R, Germani S, Vespasiani G: Stones and urinary tract infections. Urol Int 2007; 79(Suppl 1):32-36.

137 Lopalco G, Rigante D, Giannini M, Galeazzi M, Lapadula G, Iannone F, Cantarini L: Safety profile of anakinra in the management of rheumatologic, metabolic and autoinflammatory disorders. Clin Exp Rheumatol 2016;34:531-538.

138 Shibata S: A drug over the millennia: pharmacognosy, chemistry, and pharmacology of licorice. Yakugaku Zasshi 2000;120: 849-862.

139 Honda H, Nagai Y, Matsunaga T, Okamoto N, Watanabe Y, Tsuneyama K, Hayashi H, Fujii I, Ikutani M, Hirai Y, Muraguchi A, Takatsu K: Isoliquiritigenin is a potent inhibitor of NLRP3 inflammasome activation and diet-induced adipose tissue inflammation. J Leukoc Biol 2014;91:967-976.

140 Salla M, Butler MS, Pelingon R, Kaeslin G, Croker DE, Reid JC, Baek JM, Bernhardt PV, Gillam EM, Cooper MA, Robertson AA: Identification, synthesis, and biological evaluation of the major human metabolite of NLRP3 inflammasome inhibitor MCC950. ACS Med Chem Lett 2016;7: 1034-1038.

141 Juliana C, Fernandes-Alnemri T, Wu J, Datta P, Solorzano L, Yu JW, Meng R, Quong AA, Latz E, Scott CP, Alnemri ES: Anti-inflammatory compounds parthenolide and Bay 11-7082 are direct inhibitors of the inflammasome. J Biol Chem 2010; 285:9792-9802.

142 Shahid H, Singh JA: Investigational drugs for hyperuricemia. Expert Opin Investig Drugs 2015;24:1013-1030.

143 Barreyro FJ, Holod S, Finocchietto PV, Camino AM, Aquino JB, Avagnina A, Carreras MC, Poderoso JJ, Gores GJ: The pan-caspase inhibitor Emricasan (IDN6556) decreases liver injury and fibrosis in a murine model of non-alcoholic steatohepatitis. Liver Int 2015;35:953-966. 